\title{
EFEKTIFITAS MUSIK LULLABY TERHADAP DURASI TIDUR SIANG ANAK USIA TODDLER
}

\author{
Bima Doni Pranata ${ }^{1}$, Riri Novayelinda ${ }^{2}$, Sri Wahyuni ${ }^{3}$ \\ ${ }^{1,2,3}$ Fakultas Keperawatan Universitas Riau Jalan Pattimura No 9 Gedung G Pekanbaru Riau \\ Kode Pos 28131 Indonesia \\ Email: masbima0@gmail.com
}

\begin{abstract}
Abstrak
Musik lullaby merupakan salah satu musik yang memiliki karakteristik melodi yang sederhana, pola irama yang berulang yang disukai oleh anak. Penelitian ini bertujuan untuk mengetahui efektifitas musik lullaby terhadap durasi tidur siang anak usia toddler. Desain penelitian adalah quasy experiment dengan rancangan penelitian pretest-posttest design with control group. Sampel penelitian adalah 34 responden yang dibagi menjadi 17 responden kelompok eksperimen dan 17 responden kelompok kontrol yang diambil berdasarkan kriteria inklusi dengan menggunakan teknik nonprobability sampling dengan jenis purposive sampling. Pada kelompok eksperimen dilakukan pemutaran musik lullaby selama 30 menit sebelum tidur siang dalam waktu 3 hari. Alat ukur yang digunakan adalah lembar observasi untuk mengukur durasi tidur responden. Analisa data yang digunakan adalah uji dependent $t$ test dan independent $t$ test. Hasil penelitian menunjukkan ratarata durasi tidur setelah diberikan musik lullaby pada kelompok eksperimen adalah 89,41 menit dan pada kelompok kontrol yang tidak diberikan musik lullaby adalah 67,06 menit. Hasil statistik diperoleh $p$ value $(0,000)<\alpha(0,05)$, sehingga dapat disimpulkan bahwa musik lullaby efektif terhadap peningkatan jumlah durasi tidur anak usia toddler. Penelitian ini merekomendasikan agar musik lullaby dapat digunakan sebagai pengantar tidur bagi anak di masyarakat atau diruang perawatan anak.
\end{abstract}

Kata kunci : Musik lullaby, tidur siang, toddler

\begin{abstract}
Lullaby is characterized by music that has simple melodic and has repetitive rhythm patterns that are liked by children. The purpose of this study to determine the effectiveness of lullaby music on the nap duration of toddler. The research design is quasy experiment with pretest-postest design and control group design. The study sample was 34 respondent devided into 17 respondent in the experimental group and 17 respondent in the control group. The sample were taken based on inclusion criteria using with puposive sampling. The experimental group received lullaby music intervention for 30 minutes before taking a nap in 3 days. The measurung instrument used is an observasion sheet to measure the respondent's nap duration. The result showed that after intervention was 89,41 minutes and in the control group 67,06 minutes. The result of the $t$ test showed $p$ value $(0,000)<\alpha=0,05$, it can be conclude that lullaby music is effective amount of sleep duration for toddler. This research recommended that lullaby music can be used as a bedtime for children in the community or in the child care room.
\end{abstract}

Keyword : Lullaby music, nap, toddler.

\section{PENDAHULUAN}

Toddler merupakan masa ketika anak berusia 12 sampai 36 bulan, pada masa ini anak tengah mengeksplorasi lingkungannya karena anak berusaha mencari tahu bagaimana semua terjadi. Anak pada usia toddler merupakan masa yang beresiko bagi orang tua maupun anak, karena orang tua dan anak berusaha mengenal dengan baik dan orang tua memiliki peran dalam membimbing anak 
dalam mencapai tugas perkembangan. Anak pada masa ini juga anak mengalami pertumbuhan dan perkembangan yang penting (Wong et al, 2009).

Pertumbuhan dan perkembangan pada anak dipengaruhi beberapa faktor antara lain faktor prakonsepsi, prenatal, natal, dan pascanatal. Faktor pascanatal salah satunya adalah terdapat masalah pada hormonal (Zahara et al, 2013). Hormon yang dapat mempengaruhi tidur salah satunya adalah hormon adrenalin yang dapat menyebabkan aktivitas tidur anak menjadi buruk.

Aktivitas tidur merupakan bagian penting bagi pertumbuhan anak. Tidur memberikan stimulus bagi proses tumbuh kembang otak, karena $75 \%$ hormon pertumbuhan dikeluarkan saat anak tidur. Menurut Abdurrahman, Hiola dan Mursyidah (2015) hormon pertumbuhan memperbarui semua sel yang ada ditubuh hingga sel saraf otak, proses ini tetap berjalan ketika anak terlelap.

Potter dan Perry (2010) mengatakan tidur merupakan bagian dari ritme biologis untuk mengembalikan stamina. Kebanyakan bayi menghabiskan masa 1 bulan pertama kehidupannya dalam fase tidur. Usia anak yang bertambah membuat kebutuhan tidur anak semakin berkurang (Potter \& Perry, 2010). Usia 1-2 tahun merupakan peralihan dari masa bayi ke masa kanak kanak. Anak pada usia ini pada umumnya tidur pada malam hari dan tidur 2-3 jam pada siang hari. Total tidur rata-rata anak usia toddler adalah 12 jam dalam sehari (Potter \& Perry, 2010).

Potter dan Perry (2010) mengatakan, selama tidur pada fase NREM tahap IV memiliki gelombang rendah yang dapat melepaskan hormon pertumbuhan manusia untuk memperbaiki dan memperbarui sel epitel khusus seperti otak. Anak pada saat tidur semua fungsi diperbarui termasuk hormon pertumbuhan yang diproduksi tiga kali lebih banyak dibandingkan saat terbangun. Pertumbuhan tersebut meliputi otot, kulit, sistem jantung, pembuluh darah, dan tulang.

Tanjung dan Sekartini mengatakan pada usia 1-2 tahun biasanya mulai terjadi masalah tidur. Masalah tidur dapat terjadi dengan manifestasi kesulitan pada saat memulai tidur, mempertahankan tidur, atau gangguan yang berhubungan dengan pernapasan (Sinaga, 2013). Gangguan tidur pada anak dapat bersifat internal maupun eksternal. Faktor lingkungan dapat mempengaruhi kualitas tidur pada anak, demikian pula prilaku dan kebiasaan dapat dihubungkan dengan gangguan tidur.

Penelitian yang dilakukan Tanjung dan Sekartini (2016) mengatakan bahwat terdapat 3 jenis masalah tidur yang biasa dialami oleh anak yaitu disomnia, parasomnia dan gangguan tidur lainnya. Disomnia terjadi pada jumlah tidur anak yaitu saat memulai dan mempertahankan tidurnya, sedangkan parasomnia merupakan masalah yang 
Bima Doni Pranata, Riri Novayelinda, Sri Wahyuni, Efektivitas Musik Lullaby terhadap Durasi Tidur Siang Anak Usia Toddler

berhubungan dengan keadaan terjaga, terjaga sebagian atau transisi ke tahap tidur.

Anak pada saat akan memulai tidur butuh berada dalam kondisi relaksasi. Salah satu cara untuk membuat tubuh rileks adalah dengan memperdengarkan musik (Hildayani et $a l, 2014)$. Karakteristik musik yang bersifat terapi adalah musik yang nondramatis, dinamikanya bisa diprediksi, memiliki nada yang lembut, harmonis, dan temponya 60-80 beat permenit. Kekuatan suara berkisar antara 55-65 decibel atau tidak melebihi dari 65 decibel (Loewy et al, 2013). Suara yang lembut juga memiliki efek yang menenangkan dan menyegarkan pikiran sehingga tubuh menjadi rileks (Sillehu \& Susanti, 2019).

Musik yang memiliki suara lembut salah satunya adalah musik lullaby. Lullaby adalah jenis musik yang terkenal di Amerika serikat untuk dinyanyikan pada anak. Musik lullaby memiliki karakteristik melodi yang sederhana, pola dan nyanyian yang berulang, dan struktur yang sederhana (Azmi et al, 2017).

Penelitian yang dilakukan oleh Loewy, Stewart, Dassler, Telsey dan Homel (2013) dengan judul The effect of music therapy on vital signs, feeding, and sleep in premature Infants mengatakan bahwa dari hasil penelitian dari tiga intervensi musik yang diberikan terdapat perubahan pada denyut jantung yang terjadi pada musik lullaby. Musik yang diputar mempengaruhi denyut jantung menjadi lebih rendah setelah intervensi dan terdapat perbedaan dalam pola tidur.

Penelitian yang dilakukan Lubetzky, Mimouni, Dollberg, Reifen, Ashbel, dan Mandel (2009) dengan judul Effect of music by mozart on energy expenditure in growing preterm infants menemukan bahwa (Resting energy ex-penditure) REE yang sama selama 10 menit pertama dari kedua kelompok pengacakan. Periode 10 menit berikutnya, bayi yang terpapar musik memiliki REE lebih rendah secara signifikan dari pada ketika tidak terpapar musik. Hal ini juga berlaku selama periode 10 menit ketiga. Dengan demikian, rata-rata, efek pengukuran musik pada REE adalah pengurangan $10 \%$ hingga $13 \%$ dari baseline. Efek yang diperoleh dalam waktu 10 hingga 30 menit. Dengan mendengarkan musik Mozart secara signifikan dapat menurunkan REE pada bayi prematur yang sehat.

Hasil studi pendahuluan yang dilakukan di lingkungan RT 02 Kelurahan Labuh Baru Timur Pekanbaru dengan menanyakan berapa lama durasi tidur anak pada siang hari kepada 8 orang tua yang memiliki anak usia antara 1 sampai 3 tahun didapatkan hasil bahwa 7 orang anak memiliki durasi tidur siang ratarata 1 jam 30 menit dan 1 orang anak memiliki durasi tidur siang kurang dari 1 jam. Kebutuhan tidur anak seharusnya memiliki durasi tidur rata-rata 11 hingga 12 jam dalam sehari semalam dan 2-3 jam pada siang hari. 
Bima Doni Pranata, Riri Novayelinda, Sri Wahyuni, Efektivitas Musik Lullaby terhadap Durasi Tidur Siang Anak Usia Toddler

Tidur siang pada anak-anak di lingkungan RT 02 Kelurahan Labuh Baru Timur Pekanbaru tersebut membutuhkan waktu 1 jam hingga 1 jam 30 menit untuk memulai tidurnya. Cara yang dilakukan oleh orang tua untuk menidurkan dan menjaga durasi tidur anak agar tidak terbangun adalah dengan diberikan susu ketika memulai tidur dan tetap memastikan ayunan anak tetap berayun. Memberikan ayunan dan memberikan susu ternyata masih belum bisa memenuhi durasi tidur, sedangkan kekurangan tidur siang anak akan cenderung rewel dan kondisi anak menjadi kurang bugar karena tidur siang pada anak memiliki manfaat untuk mengembalikan energi. Hasil wawancara dengan orang tua anak tersebut juga mengatakan tidak pernah mendapatkan intervensi apapun untuk mempertahankan durasi tidur anak maka peneliti memberikan musik Lullaby untuk meningkatkan durasi tidur siang anak. Berdasarkan fenomena dan latar belakang serta didukung oleh penelitian sebelumnya maka peneliti tertarik untuk meneliti tentang "Efektifitas musik lullaby terhadap durasi tidur siang anak usia toddler".

\section{METODE PENELITIAN}

Penelitian ini dilakukan di Kelurahan Labuh Baru Timur Kecamatan Payung Sekaki Pekanbaru yang dimulai pada bulan Januari 2019 sampai bulan juni 2019. Jenis penelitian yang digunakan adalah quasi eksperiment dengan kelompok eksperimen dan kontrol dengan dilakukan pretest dan posttest. Populasi dalam penelitian ini adalah 3 Posyandu dengan jumlah kunjungan terbanyak di Kelurahan Labuh Baru Timur Kecamatan Payung Sekaki Kota Pekanbaru.

Pengambilan sampel menggunakan teknik nonprobability sampling dengan jenis purposive sampling dengan menggunakan rumus Slovin didapatkan 34 responden. Kriteria inklusi dalam penelitian ini adalah anak dengan rentang usia 18-24 bulan, anak yang sehat, tidak dalam mengkonsumsi obat tidur, dan orang tua bersedia mengisi informed consent untuk dilakukan penelitian kepada anak. Variabel independen dalam penelitian ini adalah pemberian musik lullaby yang diputar sebelum anak tidur siang dalam 30 menit selama 3 hari berturut-turut menggunakan smartphone yang terhubung dengan speaker portable dengan kekuatan suara 55-65 db yang diukur menggunakan decibelmeter dan variabel dependen adalah durasi tidur siang anak usia toddler. Alat yang digunakan untuk pengumpulan data adalah lembar observasi yang digunakan untuk mengukur durasi tidur siang pretest dan posttest. Pada kelompok kontrol tidak diberikan intervensi musik lullaby namun mengisi lembar observasi yang digunakan untuk mengukur durasi tidur siang pretest dan posttest.

Analisis data menggunakan analisis univariat dan bivariat. Analisis statitistik menggunkan uji beda dua mean dependent sample $t$ test dan independent $t$ test. Derajat 
Bima Doni Pranata, Riri Novayelinda, Sri Wahyuni, Efektivitas Musik Lullaby terhadap Durasi Tidur Siang Anak Usia Toddler

kemaknaan $(\alpha)$ yang digunakan dalam penelitian ini adalah 0,05.

\section{HASIL PENELITIAN}

\section{A. Karakteristik Responden}

Tabel 1

Distribusi karakteristik responden dan uji homogenitas

\begin{tabular}{|c|c|c|c|c|c|c|c|}
\hline \multirow[t]{2}{*}{$\begin{array}{c}\text { Karakteristik } \\
\text { Responden }\end{array}$} & \multicolumn{2}{|c|}{$\begin{array}{c}\text { Kelompok } \\
\text { eksperimen }\end{array}$} & \multicolumn{2}{|c|}{ Kelompok kontrol } & \multicolumn{2}{|c|}{$\begin{array}{c}\text { Jumlah } \\
(N=34)\end{array}$} & \multirow[t]{2}{*}{ P value } \\
\hline & $\mathbf{N}$ & $\%$ & $\mathbf{N}$ & $\%$ & $\mathbf{N}$ & $\%$ & \\
\hline \multicolumn{8}{|l|}{ Usia } \\
\hline 18-21 bulan & 9 & 52,9 & 12 & 70,5 & 21 & 61,7 & 0,689 \\
\hline $22-24$ bulan & 8 & 47,1 & 5 & 29,4 & 13 & 38,3 & \\
\hline Total & 17 & 100 & 17 & 100 & 34 & 100 & \\
\hline \multicolumn{8}{|l|}{ Jenis Kelamin } \\
\hline Perempuan & 9 & 52,9 & 7 & 41,2 & 16 & 47,1 & \multirow[t]{2}{*}{0,550} \\
\hline Laki-laki & 8 & 47,1 & 10 & 58,8 & 18 & 52,9 & \\
\hline Total & 17 & 100 & 17 & 100 & 34 & 100 & \\
\hline
\end{tabular}

Tabel 1 menunjukkan bahwa dari 34 (52,9\%). Hasil uji Levene test didapatkan responden yang diteliti, distribusi usia terbanyak adalah kelompok usia 18-21 bulan dengan jumlah 21 orang responden $(61,7 \%)$, bahwa usia dan jenis kelamin adalah homogen dengan $p$ value $>0,05$.

Hubungan jenis kelamin dengan durasi sedangkan jenis kelamin terbanyak adalah tidur dijelaskan dalam tabel 2.

laki-laki dengan jumlah 18 orang responden

Tabel 2

Hubungan jenis kelamin dan tingkat durasi tidur

\begin{tabular}{|c|c|c|c|c|c|c|c|c|}
\hline \multirow[t]{3}{*}{ Jenis kelamin } & \multicolumn{7}{|c|}{ Tingkat durasi tidur posttest } & \multirow{3}{*}{ Total } \\
\hline & \multicolumn{3}{|c|}{ Kelompok eksperimen } & \multirow[t]{2}{*}{ Total } & \multicolumn{3}{|c|}{ Kelompok kontrol } & \\
\hline & $30-60$ & $60-90$ & $90-120$ & & $30-60$ & $60-90$ & $90-120$ & \\
\hline Perempuan & 0 & 4 & 5 & 9 & 2 & 4 & 1 & 7 \\
\hline Laki-laki & 0 & 5 & 3 & 8 & 3 & 7 & 0 & 10 \\
\hline Total & 0 & 9 & 8 & 17 & 5 & 11 & 1 & 17 \\
\hline
\end{tabular}

Tabel 2 menunjukkan bahwa durasi tidur kontrol durasi tidur terbanyak adalah terbanyak pada kelompok eksperimen adalah perempuan sebanyak 5 orang dengan durasi perempuan sebanyak 1 orang dengan durasi 90-120 menit, sedangkan pada kelompok

90-120 menit.

\section{B. Durasi Tidur Siang pada Kelompok Eksperimen dan Kelompok Kontrol}

Tabel 3

Durasi tidur siang pada kelompok eksperimen dan kelompok kontrol

\begin{tabular}{lcccc}
\hline \multicolumn{1}{c}{ Variabel } & Mean & SD & Min & Max \\
\hline Pre test & 67,18 & 19,84 & 32 & 95 \\
Kelompok eksperimen & 68,41 & 19,94 & 40 & 115 \\
Kelompok kontrol & & &
\end{tabular}


Bima Doni Pranata, Riri Novayelinda, Sri Wahyuni, Efektivitas Musik Lullaby terhadap Durasi Tidur Siang Anak Usia Toddler

\begin{tabular}{lcccc}
\hline \multicolumn{1}{c}{ Variabel } & Mean & SD & Min & Max \\
\hline $\begin{array}{l}\text { Post test } \\
\text { Kelompok eksperimen }\end{array}$ & 89,41 & 14,40 & 62 & 116 \\
Kelompok kontrol & 67,06 & 16,29 & 35 & 107
\end{tabular}

Tabel 3 menunjukkan bahwa durasi tidur dengan standar deviasi 19,94 dan posttest pada pretest pada kelompok eksperimen adalah kelompok kontrol 67,06 dengan standar 67,18 dengan standar deviasi 19,84 dan deviasi 16,29.

posttest kelompok eksperimen adalah 89,41

dengan standar deviasi 14,40, sedangkan

pretest pada kelompok kontrol adalah 68,41

\section{Perbedaan Durasi Tidur Siang Anak}

Tabel 4

Uji normalitas data

\begin{tabular}{|c|c|c|c|}
\hline \multicolumn{2}{|c|}{ Variabel } & $n$ & p value \\
\hline \multirow[t]{2}{*}{ Pre test } & Eksperimen & 17 & 0,33 \\
\hline & Kontrol & 17 & 0,51 \\
\hline \multirow[t]{2}{*}{ Post test } & Eksperimen & 17 & 0,99 \\
\hline & Kontrol & 17 & 0,24 \\
\hline
\end{tabular}

Tabel 4 menunjukkan uji normalitas data menggunakan uji Kolmogorov-Smirnov dan independent sample t test.

didapatkan hasil pre test dan post test $p$ value Uji Dependent $t$ test untuk melihat pada kelompok eksperimen $>\alpha(0,05)$, perbedaan durasi tidur pre test dan posttest sedangkan pre test dan post test $p$ value pada kelompok kontrol $>\alpha \quad(0,05)$, maka disimpulkan bahwa kedua kelompok data terdistribusi normal, sehingga memenuhi pada kelompok eksperimen dan kontrol, sedangkan uji Independent $t$ test untuk membandingkan hasil pengukuran sesudah intervensi pada kelompok eksperimen dan kelompok kontrol yang tidak diberi intervensi.

Tabel 5

Perbedaan durasi tidur siang sebelum dan sesudah intervensi kelompok eksperimen dan kelompok kontrol.

\begin{tabular}{|c|c|c|c|c|c|}
\hline Variabel & $\mathbf{n}$ & Mean & Mesan & SD & $p$ sw/me \\
\hline \multicolumn{6}{|c|}{ Kelompok eksperimen } \\
\hline Pretest & 17 & 67,18 & \multirow{2}{*}{$-22,23$} & 19,84 & \multirow[t]{2}{*}{0.000} \\
\hline Post test & 17 & 89,41 & & 14,40 & \\
\hline Pre test & 17 & 68,41 & \multirow{2}{*}{1.35} & 19,94 & \multirow[t]{2}{*}{0,645} \\
\hline Past fest & 17 & 67,06 & & 16,29 & \\
\hline
\end{tabular}


Bima Doni Pranata, Riri Novayelinda, Sri Wahyuni, Efektivitas Musik Lullaby terhadap Durasi Tidur Siang Anak Usia Toddler

Berdasarkan tabel 5 menunjukkan bahwa kelompok eksperimen memiliki perbedaan yang bermakana pada peningkatan durasi tidur pretest dan posttest dengan hasil yang signifikan yaitu $p$ value $0,000<\alpha(0,05)$, sedangkan pada kelompok kontrol tidak memiliki perbedaan yang bermakna pada peningkatan durasi tidur pretest dan posttest dengan hasil $p$ value $0,645<\alpha(0,05)$.

Tabel 6

Perbedaan durasi tidur sesudah intervensi pada kelompok eksperimen dan kelompok kontrol

\begin{tabular}{lccccc}
\hline \multicolumn{1}{c}{ Variabel } & Mean & $\begin{array}{c}\text { Mean } \\
\text { perbedaan }\end{array}$ & SD & p value \\
\hline kelompok eksperimen & Post test & 89,41 & & 14,40 & \\
kelompok kontrol & Post test & 67,06 & 22,35 & 16,29 & 0,000 \\
\hline
\end{tabular}

Tabel 6 menunjukkan durasi tidur posttest pada kelompok eksperimen dan kelompok kontrol didapatkan perbedaan yang signifikan yaitu $p$ value $0,000<\alpha(0,05)$. Hal

\section{PEMBAHASAN}

\section{A. Karakteristik Responden}

\section{Usia}

Hasil penelitian didapatkan bahwa usia terbanyak adalah usia 18 sampai 21 bulan dengan jumlah 21 orang $(61,7 \%)$. Anak usia 18 sampai 21 bulan merupakan usia anak yang paling banyak di 3 posyandu Labuh Baru Timur Kecamatan Payung Sekaki Pekanbaru. Anak pada usia ini merupakan usia emas (golden period) karena pada masa ini anak mengalami pertumbuhan dan perkembangan yang sangat pesat, tetapi anak masih bergantung kepada orang tua dalam pemenuhan kebutuhan dasar. Anak pada usia ini senang mencoba hal baru dan menirukan apa yang dilakukan orang terdekatnya (Mascola et al, 2010). ini menunjukkan bahwa hipotesa nol (Ho) ditolak, disimpulkan bahwa musik lullaby efektif terhadap peningkatan durasi tidur siang anak usia toddler.

Hidayat dan Uliyah (2008) mengatakan bahwa kebutuhan tidur manusia bergantung pada tingkat perkembangannya, hal ini berarti semakin bertambah usia manusia maka kebutuhan tidurnya akan semakin berkurang. Penelitian ini dimulai pada anak usia 18 sampai 24 bulan yang dikelompokkan menjadi 18 sampai 21 bulan dan 22 sampai 24 bulan, sehingga kebutuhan tidur tertinggi terletak pada usia 18 sampai 21 bulan.

\section{Jenis Kelamin}

Hasil penelitian didapatkan bahwa responden anak berusia 18 sampai 24 bulan di Kelurahan Labuh Baru Timur Kecamatan Payung Sekaki Pekanbaru terbanyak adalah berjenis kelamin laki-laki yaitu sebanyak 18 orang $(52,9 \%)$. Jenis kelamin merupakan salah satu faktor yang membedakan aktifitas fisik 
Bima Doni Pranata, Riri Novayelinda, Sri Wahyuni, Efektivitas Musik Lullaby terhadap Durasi Tidur Siang Anak Usia Toddler

pada anak laki-laki dan anak perempuan. Anak laki-laki memiliki aktifitas fisik lebih banyak serta memiliki jaringan otot yang lebih banyak juga (Sulistyoningsih, 2011). Tidur siang dapat memulihkan tenaga anak setelah melakukan aktifitas fisik yang banyak sehingga dalam pemulihan dapat meningkatkan jumlah durasi tidur siang anak..

\section{B. Durasi Tidur Siang pada Kelompok Eksperimen dan Kelompok Kontrol}

Hasil penelitian didapatkan bahwa terdapat perbedaan yang bermakna pada posttest kelompok eksperimen dengan $p$ value $=0,000<\alpha(0,05)$, sedangkan pada kelompok kontrol didapatkan $p$ value $=0,64>\alpha(0,05)$ artinya tidak ada perbedaan bermakna pada posttest kelompok kontrol, hal tersebut karena tidak adanya intervensi berupa musik lullaby dan tidak adanya perlakuan seperti kelompok eksperimen.

Penelitian terkait musik lullaby adalah penelitian Azmi, Fatimah dan Emaliyawati (2017) tentang "Pengaruh terapi musik lullaby terhadap heart rate, respiration rate, saturasi oksigen pada bayi prematur" menunjukkan adanya perbedaan rata-rata heart rate, respiration rate, dan saturasi oksigen pada hari pertama sebelum diberikan musik lullaby dibandingkan hari ke tiga setelah diberikan musik lullaby dengan $p$ value $<0,05$ untuk heart rate, $p$ value $<0,05$ untuk respiration rate, dan $p$ value $<0,05$ untuk saturasi oksigen. Pemberian musik lullaby mampu membuat bayi prematur menjadi rileks. Rileks akan membuat semua organ vital menjadi lambat sehingga tubuh akan mudah mencapai siklus tidur paling dalam.

Sejalan dengan penelitian Oktora dan Purnawan (2018) yang mengatakan bahwa musik dapat meningkatkan kualitas tidur pada sesorang karena musik dapat menurunkan hormon-hormon stress, meningkatkan hormon endorphin alami (serotonin). Hal ini dapat menciptakan perasaan rileks, mengurangi perasaan takut, cemas, dan tegang serta dapat menurunkan tekanan darah, memperlambat pernafasan, detak jantung dan denyut nadi.

Kebutuhan tidur anak pada anak usia toddler adalah 11-14 jam dalam sehari semalam untuk mendukung pertumbuhan dan perkembangannya. Selain untuk mendukung untuk pertumbuhan dan perkembangan, tidur disiang hari pada anak usia toddler memiliki manfaat sebagai pemulihan energi.

Hasil pengamatan yang dilakukan selama penelitian bahwa anak yang diberikan musik memiliki peningkatan durasi tidurnya, peningkatan durasi tidur ini meningkat secara perlahan dan tertinggi pada hari ke-3 dalam pemberian musik lullaby.

\section{Perbedaan Durasi Tidur Siang Posttest Pada Kelompok Eksperimen dan Kelompok Kontrol}

Hasil uji yang dilakukan didapatkan hasil bahwa durasi tidur siang setelah diberikan musik lullaby terjadi peningkatan durasi tidur siang dengan perbedaan rata-rata 22,35 menit dengan $p$ value $0,000<\alpha(0,005)$. Hal ini 
Bima Doni Pranata, Riri Novayelinda, Sri Wahyuni, Efektivitas Musik Lullaby terhadap Durasi Tidur Siang Anak Usia Toddler

berarti ada pengaruh yang signifikan antara durasi tidur pada kelompok eksperimen sebelum dan sesudah diberikan musik lullaby.

Musik yang digunakan dalam penelitian ini adalah musik lullaby. Musik lullaby merupakan musik yang terkenal di Amerika Serikat yang diberikan kepada anak. Musik ini diperdengarkan sebelum anak tidur siang dengan durasi 30 menit. Potter dan Perry (2010) mengatakan bahwa waktu yang dibutuhkan untuk terapi supaya dapat memberikan efek teraupetik adalah minimal 10 menit. Pemberian musik untuk pertama kalinya akan mengalihkan perhatian anak sehingga anak sulit untuk fokus, dibutuhkan waktu yang lebih lama untuk pemberian musik untuk membuat anak menjadi rileks. Dibutuhkan pemberian musik yang lebih lama untuk membuat anak menjadi rileks.

Hal ini sejalan dengan penelitian yang dilakukan oleh Loewy, Stewart, Dassler, Telsey dan Homel (2013) yang menunjukkan bahwa pemberian musik lullaby selama 30 menit efektif terhadap penurunan tanda-tanda vital, tidur pada bayi prematur dengan $p$ value $0,001<\alpha(0.05)$. Hal tersebut sejalan dengan Sinaga (2013) yang mengatakan bahwa sampai saat ini musik merupakan cara yang mudah untuk mengalihkan perhatian, musik lebih sederhana, mudah dimengerti dan hampir semua orang menyukainya.

Musik mempunyai harmonisasi yang indah, sehingga ketika diperdengarkan maka harmonisasi yang indah akan masuk ke dalam telinga dalam bentuk suara (audio), menggetarkan gelombang telinga, mengguncangkan cairan ditelinga dalam, serta menggetarkan sel-sel rambut didalam koklea dan selanjutnya melalui saraf koklearis menuju otak dan menciptakan imajinasi keindahan di otak kiri dan otak kanan, yang akan memberikan dampak berupa kenyamanan dan ketenangan (Pedak, 2009).

Musik yang bersifat terapi adalah musik yang nondramatis, dinamikanya bisa diprediksi, memiliki nada yang lembut, harmonis, dan temponya 60-80 beat permenit. Musik jenis ini akan mengaktifkan hormon endorphin yang berfungsi meningkatkan perasaan rileks, mengurangi stress, mengurangi ketegangan dalam tubuh serta mempengaruhi kerja kardiovaskuler, memperbaiki sistem kimia tubuh dan memperbaiki metabolisme tubuh. Kekuatan suara berkisar antara 55-65 decibel atau tidak melebihi dari 65 decibel (Loewy et al, 2013).

\section{SIMPULAN}

Pada penelitian ini didapatkan hasil bahwa usia terbanyak adalah usia 18-21 bulan $(61,7 \%)$ jenis kelamin terbanyak adalah lakilaki $(52,9 \%)$. Hasil pengukuran rata-rata durasi tidur siang pada kelompok eksperimen sebelum diberikan musik lullaby adalah 67,18 dengan nilai minimum 32 dan nilai maksimum 95, setelah diberikan perlakuan dengan musik lullaby pada durasi tidur siang terjadi peningkatan rata-rata durasi tidur siang secara 
Bima Doni Pranata, Riri Novayelinda, Sri Wahyuni, Efektivitas Musik Lullaby terhadap Durasi Tidur Siang Anak Usia Toddler

signifikan menjadi 89,41 dengan selisih 22,235 dan nilai minimum 62, sedangkan nilai maksimum 116. Hasil uji dependen t test pada kelompok eksperimen didapatkan hasil $p$ value $=0,000<\alpha(0,05)$, artinya ada perbedaan yang sangat signifikan.

Hasil pengukuran pada kelompok kontrol diperoleh nilai rata-rata durasi tidur siang pretest adalah 68,41 dengan nilai minimum 40 dan nilai maksimum 115, tanpa diberikan perlakuan dengan diberikan musik lullaby terjadi penurunan rata-rata durasi tidur siang menjadi 67,06 dengan selisih 1,353 dan nilai minimum 35, sedangkan nilai maksimum 107. Hasil uji dependen $t$ test pada kelompok kontrol didapatkan hasil $p$ value $=0,645>\alpha$ $(0,05)$, artinya tidak ada perbedaan yang sangat signifikan.

Hasil uji independent sample $t$ test didapatkan $p$ value $=0,000<\alpha(0,05)$. hal ini disimpulkan bahwa musik lullaby mampu meningkatkan durasi tidur siang anak usia toddler.

\section{SARAN}

\section{Bagi Perkembangan praktik}

Penelitian ini diharapkan menjadi salah satu pilihan untuk meningkatkan durasi tidur pada anak usia toddler. Hal ini dikarenakan ini mudah dilakukan dan tidak memerlukan banyak biaya, waktu yang tidak lama, tidak memiliki efek samping negatif kepada anak usia toddler.

\section{Bagi masyarakat}

Hasil penelitian ini diharapkan dapat dijadikan alternatif bagi masyarakat khususnya orang tua dalam meningkatkan durasi tidur siang pada anak usia toddler. Selain mudah dilakukan musik lullaby tidak berbahaya dan tidak banyak biaya sehingga dapat diterapkan oleh semua kalangan.

\section{Bagi Penelitian Selanjutnya}

Penelitian ini diharapkan dapat menambah informasi dan rujukan bagi peneliti selanjutnya untuk melakukan penelitian terkait dengan menggunakan musik lullaby terhadap durasi tidur siang anak usia toddler.

\section{DAFTAR PUSTAKA}

Abdurrahman, S., Hiola, R., \& Mursyidah, A. (2015). Pengaruh pijat bayi terhadap kualitas tidur bayi di desa Tabumela kecamatan Tilango kabupaten Gorontalo. KIM Fakultas Ilmu Kesehatan dan Keolahragaan, 3(3).

Azmi, L., Fatimah, S., \& Emaliyawati, E. Pengaruh Terapi Musik Lullaby terhadap Heart Rate, Respiration Rate, Saturasi Oksigen pada Bayi Prematur. Padjadjaran Nursing Journal, 5(3).

Hidayat, A. A. A., \& Uliyah, M. (2008). Keterampilan dasar praktik klinik untuk kebidanan. Jakarta: Salemba Medika

Hildayani, R., Sugianto, M., Tarigan, R., \& Handayani, E. (2014). Psikologi perkembangan anak. Universitas Terbuka.

Loewy, J., Stewart, K., Dassler, A. M., Telsey, A., \& Homel, P. (2013). The effects of music therapy on vital signs, feeding, 
Bima Doni Pranata, Riri Novayelinda, Sri Wahyuni, Efektivitas Musik Lullaby terhadap Durasi Tidur Siang Anak Usia Toddler

and sleep in premature infants. Pediatrics, 131(5), 902-918.

Lubetzky, R., Mimouni, F. B., Dollberg, S., Reifen, R., Ashbel, G., \& Mandel, D. (2010). Effect of music by mozart on energy expenditure in growing preterm infants. Pediatrics, 125(1), e24-e28.

Mascola, AJ, Bryson, SW, \& Agras, WS. (2010). Picky eating during childhood: a longitudinal study to age 11 years, Eating Behavior. 11(4)

Oktora, S. P. D., \& Purnawan, I. (2018). Pengaruh Terapi Murottal Al Qur'an terhadap Kualitas Tidur Lansia di Unit Rehabilitasi Sosial Dewanata Cilacap. Jurnal Keperawatan Soedirman, 11(3), 168-173.

Pedak, M. (2009). Mukjizat Terapi Qur'an untuk Hidup Sukses. Jakarta: Wahyumedia

Potter, P. A., \& Perry, A. G. (2010). Fundamental of nursing. Jakarta: Salemba Medika.

Sherwood, L. (2012). Fisiologi Manusia:Dari Sel ke Sistem. Jakarta: EGC

Sinaga, T. (2013). Musik klasik sebagai alternatif mengatasi gangguan tidurpada penderita insomnia. Jurnal pengabdian kepada masyarakat, 19(72), 88-97.

Sulistyoningsih, H. (2011). Gizi untuk kesehatan ibu dan anak.Yogyakarta: Graha Ilmu, 128.
Sillehu, S., \& Susanti, I. (2019). Pemberian Terapi Musik Instrumental untuk Menurunkan Tekanan Darah Lansia di Negeri Herlauw Pauni Seram Utara Barat Kabupaten Maluku Tengah. Jurnal Penelitian Kesehatan "SUARA FORIKES "(jurnal of health research" Forikes Voice”), 10(1), 45-48

Swarjana, I. K. (2015). Metodologi penelitian kesehatan (Edisi Revisi). Yogyakarta: Penerbit Andi.

Tanjung, M. C., \& Sekartini, R. (2016). Masalah Tidur pada Anak. Sari Pediatri, 6(3), 138-42.

Wong, D, L., Hockenberry, M., Wilson, D., Winkelstein, M, L., \& Schwartz, P. (2009). Buku ajar keperawatan pediatrik. Jakarta: EGC.

Wulandari, F. (2013). Penerapan Metode Pembelajaran Problem Solving Untuk Mengurangi Kecemasan Siswa Dalam Pembelajaran Matematika (Ptk Pembelajaran Matematika Kelas Viii Semester Gasal Smp Negeri 2 Manyaran Tahun 2012/2013)(Doctoral dissertation, Universitas Muhammadiyah Surakarta).

Zahara, D. S., Hartanto, F., \& Adyaksa, G. (2013). Hubungan antara gangguan tidur dengan pertumbuhan pada anak usia 3-6 tahun di kota Semarang (Doctoral dissertation, Diponegoro University) 